\title{
Atlantis
}

Critical Studies in Gender, Culture \& Social Justice

Études critiques sur le genre, la culture, et la justice

\section{Meat! A Transnational Analysis}

\section{Élisabeth Abergel}

Volume 42, numéro 1, 2021

URI : https://id.erudit.org/iderudit/1082018ar

DOI : https://doi.org/10.7202/1082018ar

Aller au sommaire du numéro

Éditeur(s)

Mount Saint Vincent University

ISSN

1715-0698 (numérique)

Découvrir la revue

Citer ce compte rendu

Abergel, É. (2021). Compte rendu de [Meat! A Transnational Analysis]. Atlantis, 42(1), 67-69. https://doi.org/10.7202/1082018ar d'utilisation que vous pouvez consulter en ligne.

https://apropos.erudit.org/fr/usagers/politique-dutilisation/ 


\title{
Meat! A Transnational Analysis
}

\author{
by Élisabeth Abergel
}

Élisabeth Abergel is professor in the department of Sociology and the Institute for Environmental Science (ISE) at the Université du Québec à Montréal (UQAM). Her main area of study has been the link between Science and Technology Studies and Critical Food Studies. She studies how technological convergence and new life technologies construct the future of agriculture and food, revealing much about human/nature relations. Her current research centers around a critical analysis of cultured meat and the bioprinting of living tissues for food and/or biomedical use. She is also leading a research project in partnership with the the Secrétariat à la Condition Féminine (SCF) that aims to assess women's labour in agriculture.

Book under review: Chatterjee, S., \& B. Subramaniam, eds. 2021. Meat! A Transnational Analysis. Durham: Duke University Press.
A nimal flesh and its analogues (plant-based meat and cell-based meat) and the sociopolitical and cultural transformations of diets in light of the pandemic and the climate crisis have sparked the interest of scholars from different disciplinary fields. As it turns out, the study of meat as a product of material and symbolic culture is a powerful vehicle for understanding biopolitics. Feminist critical animal and food studies scholars, such as Carol J. Adams (1990), Elspeth Probyn (2000), Carrie Hamilton (2016), Lisa Kemmerer (2011), and Amie Breeze Harper (2010) have analyzed meat in relation to the body, masculinities, human exceptionalism, sexual identities, and subjectivities, as well as gender/species intersections. They have provided us with an interesting lens from which to make sense of the politics of eating and its complex gendered, classist, and racial dimensions. Recent works by these and other authors have tackled the meat issue with regards to human and nonhuman relationships in the context of climate change and the ravages of industrial farming as well as the central role that technology plays in agriculture and food. While all of these studies shed important light on the significance of meat as commodity and as the locus of social, ethical, and cultural processes, few books assemble critical writings from a transnational, intersectional, and postcolonial perspective. Meat! A Transnational Analysis fills this gap.

In a collection of twelve essays, part of the ANIMA Critical Race Studies Otherwise Series, editors Sushmita Chatterjee and Banu Subramaniam, both Women, Gender, and Sexuality Studies professors, tackle the topic of meat outside the usual contemporary framings as a means to engage readers with far-ranging topics such as race, class, gender, sexuality, ableism, empire, capitalism, nationalism, and sustainability. Moving beyond narrow conceptualizations of meat, the authors in this collection consider the topic as a constantly mutating social object: "a site for transnational flows, colonial circuits, and varied mediated significations of gender, race, and class" (2). 
The introductory chapter, entitled "How to Think with Meat," challenges our thinking about meat as a continually evolving category within and across various political, social, geographical, cultural, and bodily contexts. Rather than focusing on the "politics of meat," the authors interrogate what they call the "politics of becoming meat," and delve into "its varied constructions based on social exigencies, disciplinary framings and economic rationalities" (3) from different epistemological perspectives. Posing the question what and who becomes meat opens up important transdisciplinary perspectives on shifting identities and global and local dimensions of meat political economies, as well as technologized forms of domination.

Turning to the issue of colonialism, imperialism, and post-colonial critiques, several authors provide interesting historical as well as social analyses of food histories. Two chapters, for example, deal with reindeer meat in the colonization of Alaskan natives and of the Sami people post-Chernobyl. In the Alaskan case, Jennifer A. Hamilton studies the transit of reindeer and frozen reindeer meat starting in the 1890 s as a means of creating colonial subjects. By framing the reindeer as a tool of northern colonization, by turning native Alaskan hunters into herdsmen and the "unproductive" Northern landscape and vegetation into meat, Hamilton shows how this civilizing process took root in polar expeditions and US expansion into the Arctic. She retraces how the imperial transit of frozen meat to elite New York restaurants and establishments was permitted through freezing and cold storage technologies. She frames "Eskimo" representations in US advertising in order to highlight colonial discourse around Arctic and food imaginaries. Anita Mannur's chapter, also on the topic of reindeer meat, analyzes the effects of radioactive fallout from Chernobyl on the Sami people's traditional way of life as herders and the rise of the new Nordic cuisine as an expression of true Nordicity. By questioning the "complex relationship between consumption, culinary appropriation, indigeneities and environmental justice" (123), she opposes the invisibility of radioactive contamination, the Sami people, and their herds to the "fetishized" culinary use of reindeer meat in the context of postnuclear violence. Her piece shows how culinary trends such as the new Nordic cuisine perpetuate age-old colonial relations of power and race by framing the local as exotic and the exotic as local and by situating white Nordic identity outside threatened Indigenous practices, all the while ignoring the effects of consuming radioactive reindeer flesh.
Irina Aristarkhova's piece, "Eating the Mother," discusses the tensions expressed in Jess Dobkin's performance artpiece entitled The Lactation Station Breast Milk Bar (2006-16) in which the public is invited to taste donated breast milk. Drawing from previous work on the maternal body as matrix in relation to the concept of hospitality, Aristarkhova investigates the relationship between anthropophagy and cannibalism. In other words, the author asks, "Is the mother food? If, so what kind? And does the self, non-self relation to maternal body imply cannibalism, autophagy, anthropophagy or something else?" (9). This discussion sets up a feminist, postcolonial, and queer inquiry into the use and limits of maternal milk and its ambiguous status as food. Here, because the mother is seen as giving of her flesh during gestation and breastfeeding, she is construed as both fluid and meat, the original food. Gestation is "digestion and ingestion of the self by the self" (49), an act of cannibalism and autophagy. This text presents new feminist, critical, queer, and postcolonial readings of cannibalism, a category used by colonizers to dehumanize, exoticize, and racially oppress non-European others. Hence, positing the mother as food opens up new ways of thinking about the political and affective dimensions of the maternal body.

Angela Willey's chapter presents an engaging take on fake meat. The idea of "inauthenticity" as a personal and political issue allows for "thinking through a queer feminist and critical trans lens while being attentive to the work the supposed inauthenticity of fake sex/fake meat/ fake masculinity and femininity does to naturalize the supposedly authentic original" (242). Hence, Willey uses fake meat as a conceptual maneuver to discuss the sexual and gender politics of resistance and representation.

Elspeth Probyn's discussion of white fish as "not-fishy fish" in the American diet is worth mentioning as it draws on her work on the future of oceans. Consumers' taste for bland-tasting fish started when seafood buyers marketed the Patagonian toothfish, an ancient deep-sea species that thrives in cold Southern oceans, as Chilean seabass. Much like toothfish, the example of slimehead fish, also known as orange roughy, reveals the disastrous ecological and social consequences of an insatiable appetite for white fish. Probyn sees the search for white fish as a product of racial and ethnic inequalities between the global north and south, signalling the ultimate demise of large and ancient fish species and fishing communities, as well as oceans. 
Several chapters focus on Indian meat politics, tackling governance practices and meat bans (in particular beef and slaughter bans) as a strategy to advance Hindu nationalism and new forms of anti-Muslim politics. In her chapter, Chatterjee uses Stacy Alaimo's concept of transcorporeality to discuss meat and yoga as two aspects of the body politic in India. Beef bans and India's renewed interest in yoga produce different kinds of state-based corporeality: the violence of beef bans that target Muslims on the one hand and the pacifism of yoga, as a wellness and spiritual practice, that targets a transnational public (mostly European), on the other. In both cases, Hindu nationalist anti-meat politics and yoga as a multicultural symbol of India reveal how corporeal politics work by defining exclusion and inclusion of certain bodies broadly imagined as "meat." More than a set of body practices, Chatterjee argues that yoga is a symbol of health and non-meat-eating Indian masculinity, a cure against Western modernity, and transnational politics by other means.

Parama Roy's chapter, "On Being Meat: Three Parables on Sacrifice and Violence," poses the question of sacrifice and its relationship to violence in both animal sacrifice and human self-sacrifice. A survey of specific texts justifying animal sacrifice and rationalizing suffering provide the background for examining what Roy calls the paradox of self-sacrifice. Bishnoi women breastfeeding orphaned fawns offer insight into the moral processes of this paradox: when the women save gazelles but not the wild dogs threatening them, their self-sacrificial acts justify violence and the suffering of other species. Thus, Roy examines the notions of sacrifice, violence, suffering, and the moral processes that determine who becomes meat using Western philosophical and Vedic traditions, leading the author to conclude that "who eats and who gets eaten can then be flexibly contingent rather than unyieldingly predictable" (176).

By questioning the boundaries between human/animal/ plant categories, and blurring those boundaries, several authors (see chapters by Neel Ahuja and Banu Subramaniam) expand the notion of meat not simply as commodity but within a process of becoming self, nonself, or other. The collection as a whole goes beyond the eater/eaten dichotomy to such an extent that, in some of the chapters, the issue of who or what is meat gets transposed. This complex and multilayered understanding of meat introduces readers to a wide range of methodological approaches and theoretical tools as well as the connections between different framings of meat and struc- tures of domination beyond race, class, and gender categories. Even though chapters are uneven-some are more analytical and empirical, while others are more experimental and undertheorized - this is compensated for by the diversity of topics and the original epistemological directions taken by some authors. Readers of Atlantis and feminist scholars in general will no doubt find this edited volume useful and interesting.

\section{Works Cited}

Adams, C. J. 1990/2010. The Sexual Politics of Meat: A Feminist-Vegetarian Critical Theory. New York: Continuum.

Hamilton, C. 2016. "Sex, Work, Meat: The Feminist Politics of Veganism.” Feminist Review. 114: 112-129.

Harper, Amie Breeze. 2010. "Race as a 'Feeble Matter' in Veganism: Interrogating Whiteness, Geopolitical Privilege, and Consumption Philosophy of 'Cruelty-free' Products." Journal for Critical Animal Studies. 8.3: 5-27.

Kemmerer, L. 2011. Sister Species: Women, Animals and Social Justice. Urbana: University of Illinois Press.

Probyn, E. 2000. Carnal Appetites: FoodSexIdentities (1st ed.). London: Routledge. 